\title{
HEALTH BELIEF MODEL AND PRECEDE PROCEED ON THE USE OF ANTENATAL CARE AND THE RISK OF PREECLAMPSIA IN KEDIRI, EAST JAVA
}

\author{
Katmini $^{1,2)}$, Bhisma Murti3), Tedjo Danudjo Oepomo4), Sapja Anantanyu ${ }^{2)}$ \\ 1)School of Health Sciences Bhakti Mulia, Kediri, East Java \\ 2)Doctoral Program in Community Development and Empowerment, \\ Sebelas Maret University \\ 3)Masters Program of Public Health, Sebelas Maret University \\ 4)Department of Obstetrics and Gynecology, Faculty of Medicine, Sebelas \\ Maret University
}

\begin{abstract}
Background: Preeclampsia is the leading cause of maternal death in developing countries. Maternal mortality rate (MMR) is still high in Indonesia. MMR was reported at 97.39 deaths/ 100,000 live births in East Java. This study aimed to determine the factors associated with the utilization of antenatal care and the risk of preeclampsia using Health Belief Model and PRECEDE PROCEED model.

Subjects and Method: This was an observational analytical study with case control. The study was conducted in Kediri District, East Java, from October 11, 2016 to March 8, 2017. A sample of 160 pregnant women were selected for this study using fixed disease sampling, consisting of 40 pregnant women with preeclampsia and 120 pregnant women without preeclampsia. The dependent variables were use of antenatal care and preeclampsia. The independent variables were perceived barriers, cues to action, and social support. The data were collected using questionnaire and analyzed by path analysis.

Results: Preeclampsia was negatively associated with the use of antenatal care $(b=-0.91 ; 95 \% \mathrm{CI}=-1.65$ to $-0.17 ; \mathrm{p}=0.015)$. The use of antenatal care was positively associated with existence of cues to action $(b=0.70 ; 95 \% \mathrm{CI}=$ 0.03 to $1.36 ; \mathrm{p}=0.038)$ and strong social support $(\mathrm{b}=0.72 ; 95 \% \mathrm{CI}=0.04$ to $1.41 ; \mathrm{p}=0.038)$. The use of antenatal care was negatively associated with perceived barrier $(\mathrm{b}=-0.89 ; 95 \% \mathrm{CI}=-1.56$ to $-0.22 ; \mathrm{p}=0.009)$.

Conclusion: Preeclampsia is associated with the use of antenatal care. The use of antenatal care is associated with cues to action, social support, and perceived barrier. Health Belief Model and PRECEDE PROCEED can be used to study factors associated with the use of antenatal care and the risk of the preeclampsia.
\end{abstract}

Keywords: the use of antenatal care, preeclampsia, Health Belief Model, PRECEED PROCEED model

Correspondence: Katmini. Prodi Keperawatan STIKES Bhakti Mulia Kediri. 